\title{
6 Langkah Menjadi Profesional Manajemen Sumber Daya Manusia yang Handal
}

\section{Darmadi Ismail}

\author{
STKIP PGRI Sidoarjo \\ suhairmikhail@protonmail.com
}

Manajemen Sumber Daya Manusia (SDM) penting bagi setiap perusahaan dengan karyawan. Jika Anda hanya perusahaan kecil, Anda mungkin mengelola SDM atau Human resource $(\mathrm{HR})$ sendiri, sementara sebagian besar perusahaan besar memiliki seluruh divisi yang didedikasikan untuk menemukan dan mempertahankan staf yang tepat. Ini adalah pekerjaan yang membutuhkan kebijaksanaan, dedikasi, dan organisasi. Seperti halnya sektor bisnis apa pun, mengelola SDM memiliki pasang surut, tetapi sebagian besar masalah dapat diselesaikan dengan mudah dengan kiat-kiat berikut.

\section{Tetap terorganisir}

Ketika menyangkut pengelolaan SDM, penting bahwa semuanya memiliki tempatnya, karena barang dan file yang hilang dapat menjadi sangat penting di jalurnya. Untuk perusahaan besar, sangat penting untuk memiliki perangkat lunak intranet HR yang beroperasi 
hari ini karena sangat sedikit yang dilakukan tanpa internet, atau setidaknya portal intranet. Menjaga semuanya tetap rapi dan rapi dan mereka dapat ditemukan saat dibutuhkan. Menjadi terorganisir juga membantu ketika ada banyak hal yang harus dikelola sekaligus. Multitasking adalah kata yang penting di sini, dan ini adalah salah satu hal utama yang harus dikuasai oleh seorang manajer SDM. Ada banyak potensi masalah yang dapat dimiliki staf dan sangat sering mereka semua perlu ditangani secara bersamaan.

\section{Memiliki kejelasan}

Dalam banyak kasus, manajer SDM harus berurusan dengan situasi yang tidak jelas. Apakah itu pelecehan seksual? Diskriminasi? Ada banyak tekanan untuk memutuskan hasil ketika ada area abu-abu, dan penting untuk mengetahui kapan harus membuat keputusan tegas sendiri, dan kapan harus meminta bantuan kepada rekan atau manajer. Dalam kasus ini, sangat membantu untuk mengasah kemampuan negosiasi dan mediasi dan untuk mempelajari cara mengelola konflik karena tidak semua kasus dapat diselesaikan dengan mudah atau diterima oleh semua pihak. Jelas, tujuannya adalah membuat kedua / semua pihak senang dengan hasilnya, dan itu tidak selalu mudah dicapai. Sikap yang baik dan kemampuan pemecahan masalah datang dengan kebutuhan untuk bernegosiasi - 
penting bahwa semua orang, sementara mereka mungkin tidak (dan mungkin tidak) saling menyukai, setidaknya berhasil menjadi orang sipil. Itu pekerjaan SDM, dan itu tidak selalu mudah.

\section{Jadilah diskrit, bijaksana dan etis}

Mengelola Sumber Daya Manusia dapat menjadi sedikit tindakan penyeimbangan. Terkadang penting untuk melindungi individu sementara waktu lain sangat penting untuk mengutamakan perusahaan. Manajer HR dimaksudkan untuk mendengarkan kekhawatiran karyawan tetapi juga dituntut untuk menegakkan kebijakan perusahaan.

Menjadi agak tangguh adalah nama permainan dan ketika karyawan membutuhkan batasan, penting bagi mereka untuk tetap berada di dalam parameter perusahaan. Setelah mengatakan ini, mereka perlu tahu bahwa pendapat mereka aman dan apa yang dikatakan HR dianggap serius.

\section{Intensif komunikasi}

Salah satu keterampilan yang paling penting untuk dimiliki dalam manajemen SDM adalah komunikasi. Manajer SDM perlu melaporkan kepada manajer yang lebih tinggi, kepala departemen lain, staf mereka sendiri, staf departemen lain, bos dan karyawan potensial dan bahkan masa lalu karena menjaga semua orang pada halaman yang sama sangat 
penting dalam bidang bisnis ini. Tindakan menyeimbangkan dan menyeimbangkan terus-menerus, manajemen SDM adalah pekerjaan yang menuntut tetapi semoga tips ini akan membantu Anda sukses dalam peran bisnis yang terus berubah dan sangat penting ini.

\section{Anda membutuhkan spesialisasi SDM}

Bahkan jika Anda seorang generalis dan jack of all trades, Anda harus menjadi Master of One. Itu membuat Anda unik, istimewa dan membuat Anda berbeda dari yang lain.

\section{Hasil HR sangat berarti, tetapi hubungan lebih penting}

Melakukan dan menyampaikan hasil penting. Mereka membantu Anda menarik perhatian, pengakuan, penghargaan, dan promosi. Tetapi hanya sampai titik tertentu. Ketika Anda mencapai jajaran kepemimpinan Sumber Daya Manusia, perspektif ini bergeser secara radikal. Hasilnya tetap sama pentingnya, tetapi hubungan yang Anda bangun dalam organisasi membawa beban yang lebih besar.

Mempelajari dan mengembangkan potensi agar menjadi profesional manajemen sumber daya manusia (MSDM) yang handal sangat menarik dan menantang. 


\section{Reference}

Clapon, P. (2015). 4 Tips for Human Resource Management Success. Retrieved April 29, 2018, from https://gethppy.com/employeeengagement/4-tips-for-human-resourcemanagement-success

KBBI. (2017). Sumber. Retrieved April 30, 2018, from https://kbbi.web.id/sumber Purnomo, A., Putri, R. A., \& Rosyidah, E. (2017). Kamus Manajemen Sumber Daya Manusia. Sidoarjo: UNUSIDA Press.

Sohn, P. (2012). 30 Powerful Tips to Be an Outstanding HR Professional. Retrieved April 25, 2018, from http://paulsohn.org/30-powerful-tips-to-bean-outstanding-hr-professional/ 